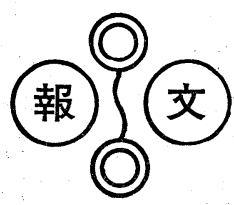

コークス中の窒素定量法について（I）

共同実験の解析

- 1978. 11. 21 受理一

\begin{abstract}
日 本 鋼 管 (株) 大西 利英子*，宮津 隆** 公害資源研究所 似鳥次 郎***
\end{abstract}

\section{1. 緒言}

コークスの窒素分は，從来いわば「工業的にはほと んど意味のない成分」と考兄られていた。強いていえ ば, 終戦後の食料難一肥料不足の時代に, コークス工 場に䑙ける硫安生産管理のために，コークス炉の窒素 収支計算に用いられていたことがあるにすぎない。し たがって, コークス中の窒素分析方法の研究は, 日本 に限らず世界各国ともここ20数年間はほとんど行なわ れなかったといっても過言ではない。

しかし，近年環境問題が重視され，製鉄業に括预る $\mathrm{NO}_{x}$ の発生が問題となるに及んで, コークス中の窒 素が問題視されるようになった。それは，製鉄所で発 生する $\mathrm{NO}_{x}$ の約 $40 \%$ が焼結工場に 起因するるの であり，そして兢結工場から発生する $\mathrm{NO}_{x}$ のほとん どすべてが，焼結然料として用いられるコークス中の 窒素に起因することが判明しているからである。

製鉄業に乱いては, コークス中の窒素低減あるいは 排煙脱硝の種々の方策が検討されつつある。しかしな がら，実用化にはまだ技術的あるいは経済的な難問を 多く残している。日本にとって $\mathrm{NO}_{x}$ の環境問題は, 今後も極めて重要であると考兄ら，そのためコーク ス中の窒素量を正確に推定することが急務となってい る。

これまでコークス中の窒素の分析は, 石炭の分析法 に準拠して取り扱われてきた。しかし，石炭はコーク スと異なりかなりグラファイト化して和り，試料によ っては，これらの分析法では分析が困難であることも 多く，分析值の信頼性が問題となっている。

日本に和ける石炭就よびュークス中の窒素分析法の

\footnotetext{
*技術研究所第四研究部分析研究室

**技術研究所第一研究部石炭研究室 川崎市川崎区 南渡田町 1 の 1

***公害資源研究所資源第 3 部第 3 課 埼玉県川口市 川口 3 の 1 の 1
}

標準化に関する経緯は, A. E. Beet, R. Belcher に より提案されたセミミクロケルダール法抢よびセミミ

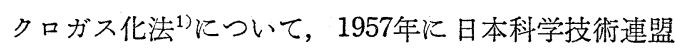
サンプリング研究会が協同実験を行ない，検討を加 光，JIS の原案を作成し，1959年に JISM 8813 とし て制定された。一方, ISO では1969年にセミミクロ ケルダール法が ISO/R926 として採用されたが， JIS 法と比較すると, 試料の分解時に, 分解促進剂で あるセレンを加えていない点が異なっている。これ は，セレンを分解触媒として用いると，硫酸分解によ り生成した硫酸アンモニウムをさらに窒素にまで分解 してしまい，その結果定量值が低くなるという見解に よっている。

これらの事情を背景に, 上述のサンプリング研究会 では, 現状の JIS 法がコークス中の 窒素分析法とし て妥当であるかどうか，また，七ミミクロケルダール 法について ISO 法と JIS 法で差があるかどうか， これらの問題について検討を行なうため協同実験を企

Table 1 Proximate analysis of roundrobin coke samples

\begin{tabular}{clrcr}
\hline No. & \multicolumn{1}{c}{ Cokes } & Ash & V.M. & F.C. \\
\hline 1 & Foundry Coke & 7.6 & 0.5 & 91.9 \\
2 & Metallugical Coke & 11.4 & 0.5 & 88.1 \\
3 & $\begin{array}{l}\text { Coke 1 } \\
\text { (U.S., L. V. Coal) }\end{array}$ & 8.7 & 0.7 & 90.6 \\
4 & $\begin{array}{l}\text { Coke 2 } \\
\text { (U.S., H. V. Coal) } \\
\text { *Dissected B. F. Coke } \\
\text { (Bosh) }\end{array}$ & 12.7 & 0.8 & 86.5 \\
6 & $\begin{array}{l}\text { *Dissected B.F. Coke } \\
\text { (Lower Shaft) }\end{array}$ & 16.3 & 1.4 & 82.1 \\
$7 \begin{array}{c}\text { *issected B. F. Coke } \\
\text { (Upper Shaft) }\end{array}$ & 13.7 & 1.5 & 84.8 \\
\hline
\end{tabular}

* Samples were taken from dissected blast furnace after shut down. 
した。同時に，現在かなり日常分析に用いられている 機器分析法と, JIS 法あるいは ISO 法との定量值の 差違についても，比較検討を行なった。以下，これら の結果について報告する。

\section{2. 実験}

2.1 コークス試料

Table 1 に示した種類のコークスについて定量を行 なった。これらの試料は，それぞれ60メッシュ(250 $\mu \mathrm{m})$ 以下に微粉砕して，十分に攪抖混合したのち，2 分器により分割して分析所に配布された。 なお，試料調製所はつぎのと晾りである。 東京瓦斯(株)（No.1 鋳物用コークス） 新日本製鉄(株)（No.2 高炉用コークス） 川崎製鉄(株)（No.3 低揮発分炭コークス） " (No.4 高揮発分炭ニークス)

日本鋼管(株)（No.5 高炉解体コークス高温部） "l (No.6 高炉解体コークス中温部) " (No.7 高炉解体コークス低温部)

\section{2 分析方法}

検討した分析方法は, JISM 8813 のセミミクロケ ルダール法叔よびセミミクロガス化法, ISOであるセ レン触媒を用いないセミミクロケルダール法, 参加分 析所でそれぞれ採用している各種の機器分析法, の4 通りの方法である。参加分析所は，このうち可能な分 析方法（1つとは限らない）で 1 試料につき独立に 2 回の測定を行ない，測定值は無水ベースに換算し，有 効数字 3 けたで報告するものとした。実験方法の概略 は以下のと拈りである。

\section{2 .1 セミミクロケルダール法}

試料 $0.1 \mathrm{~g}$ のをミクロケルダールフラスコに入れ, 硫酸 $4 \mathrm{ml}$ 和よび触媒として硫酸カリウム, 硫酸第 2 水銀，（セレン粉末）の $32: 5:$ (1) の混合物 $2 \mathrm{~g}$ を 加兄，加熱分解する。分解が終了し液が透明となった ら加熱を止める。次にこれを水蒸気蒸留して, 発生す るアンモニアを㴗う酸溶液中に吸収後, N/100 硫酸 で滴定して窒素量を求める。

\section{2 .2 セミミクロガス化法}

磁製ボートに試料 $0.1 \mathrm{~g}$ とソーダ石灰約 $2 \mathrm{~g}$ を入 れ，950 1000 $\mathrm{C}$ 飞昇温した管状電気炉内の石英製の 燃焼管中に装入し，水蒸気を送りながら分解する。 $2 \mathrm{~N}$ 硫酸吸収液中に捕集された窒素を，七ミミクロケ ルダール法と同樣に, 蒸留後硫酸溶液で榈定して求市 る。

\section{2 .3 機器分析法}

有機物中の 窒素分析に 現在広く利用されているの
は，試料を完全然焼後，分解ガス中の窒素分をすべて $\mathrm{N}_{2}$ の形にして定量する Duma 法の原理に基づいた 装置であるき。ただし'定量系としては，二酸化炭素中 で熱分解後， $\mathrm{N}_{2}$ 量を容量法で定量する方法の他に, 酸素気流中で燃焼し，分解ガスの熱伝導度を測定する 方法などがある。

\section{3 参加分析所}

協同実験に参加した分析所は，つぎの30分析所であ る。

$\begin{array}{lc}\text { 安部商事(株) } & \text { 川崎製鉄(株)（2 事業所） } \\ \text { 川鉄化学(株） } & \text { 関西熱化学(株)（ } 3 \text { 事業所） } \\ \text { 神戸製鋼(株) } & \text { 新日本製鉄(株)（ } 9 \text { 事業所） } \\ \text { 住金化工(株)（2 事業所） 住友金属工業(株) }\end{array}$

(財)石炭技術研究所東京工業試験所日本鋼 管(株) ( 3 事業所) 三井鉱山(株) 三井鉱山 コークス(株) 三菱化成工業(株) ( 2 事業所)

(株)柳本製作所

また分析方法別の参加分析所数は, セミミクロケル ダール法17分析所, セミミクロガス化法 9 分析所, 機 器分析法15分析所であった。

\section{3. 実験結果と解析}

\section{1 测定值}

各方法ごとに得られた実験結果を Table 2，3，4 亿 示した。また, JIS 8402による異常値検定の結果, 異 常値と判定されたものを表中に示した。ただし， Table 4 の機器分析法による測定值のうち，B および $\mathrm{H}$ の分析所の測定值は, 次の理由により 異常值とし た。燃焼温度の一番低い B 分析所の測定值は，すべ ての試料について最小值となっており，燃焼温度が低 いため分解が不十分であったと推定される。H 分析 所の值は，逆に高目に出ているが，他所と異なる点 は, 試料を再粉砕して200メッシュ $(74 \mu \mathrm{m})$ 以下とし たことである。したがって，分析条件が他所と異なる と考穴られる。

Table 2，3，4を見比べると，3 方法の中では，機 器分析法がもっとも定量值のバラッキが大きいこと, 試料 No. $3 ， 5$ の低揮発分炭コークス抢よび高炉解体 コークス (高温部) といった試料では, 分析方法の違 いによる定量值の差が大きいことなどが認められる。 Table 2 の Q 分析所住異常值が多く現われているが, これは分解時間を 2 時間と一定にしているため, 試料 によっては分解が不十分であったことによるものと推 定される。

\section{2 分析精度}

分析精度を求めるために，各方法执よび試料別泟一一 
Table 2 Observed values by Semi-micro Kjeldahl method

(\%)

\begin{tabular}{|c|c|c|c|c|c|c|c|c|c|c|c|c|c|c|}
\hline \multirow{2}{*}{$\begin{array}{l}\text { Sample } \\
\text { Ca. } \\
\text { Lab. }\end{array}$} & \multirow{2}{*}{$\begin{array}{l}\text { No. } \\
\text { Se }\end{array}$} & \multirow{2}{*}{$\begin{array}{l}1 \\
-\end{array}$} & \multicolumn{2}{|r|}{2} & \multicolumn{2}{|r|}{3} & \multicolumn{2}{|c|}{4} & \multicolumn{2}{|l|}{5} & \multicolumn{2}{|l|}{6} & \multicolumn{2}{|l|}{7} \\
\hline & & & $\mathrm{Se}$ & - & $\mathrm{Se}$ & - & $\mathrm{Se}$ & - & $\mathrm{Se}$ & - & $\mathrm{Se}$ & - & $\mathrm{Se}$ & - \\
\hline A & $\begin{array}{l}1.19 \\
1.25\end{array}$ & $\begin{array}{l}1.27 \\
1.27\end{array}$ & $\begin{array}{l}0.89 \\
0.90\end{array}$ & $\begin{array}{l}0.90 \\
0.91\end{array}$ & $\left(\begin{array}{l}0.62 \\
0.60\end{array}\right)$ & $\begin{array}{l}0.50 \\
0.65\end{array}$ & $\begin{array}{l}0.59 \\
0.58\end{array}$ & $\begin{array}{l}0.59 \\
0.62\end{array}$ & $\left(\begin{array}{l}0.20 \\
0.22\end{array}\right)$ & $\begin{array}{l}0.19 \\
0.21\end{array}$ & $\begin{array}{l}0.76 \\
0.76\end{array}$ & $\begin{array}{l}0.79 \\
0.78\end{array}$ & $\begin{array}{l}0.91 \\
0.91\end{array}$ & $\begin{array}{l}0.92 \\
0.93\end{array}$ \\
\hline B & $\begin{array}{l}1.31 \\
1.30\end{array}$ & $\begin{array}{l}1.30 \\
1.31\end{array}$ & $\begin{array}{l}0.91 \\
0.91\end{array}$ & $\begin{array}{l}0.89 \\
0.93\end{array}$ & $\begin{array}{l}0.74 \\
0.72\end{array}$ & $\begin{array}{l}0.71 \\
0.67\end{array}$ & $\begin{array}{l}0.74 \\
0.74\end{array}$ & $\begin{array}{l}0.74 \\
0.72\end{array}$ & $\begin{array}{l}0.33 \\
0.34\end{array}$ & $\begin{array}{l}0.33 \\
0.33\end{array}$ & $\begin{array}{l}0.83 \\
0.81\end{array}$ & $\begin{array}{l}0.79 \\
0.78\end{array}$ & $\begin{array}{l}0.97 \\
0.94\end{array}$ & $\begin{array}{l}0.92 \\
0.92\end{array}$ \\
\hline C & $\begin{array}{l}1.34 \\
1.34\end{array}$ & $\begin{array}{l}1.35 \\
1.33\end{array}$ & $\begin{array}{l}0.96 \\
0.95\end{array}$ & $\begin{array}{l}0.95 \\
0.96\end{array}$ & $\begin{array}{l}0.75 \\
0.75\end{array}$ & $\begin{array}{l}0.71 \\
0.70\end{array}$ & $\begin{array}{l}0.71 \\
0.71\end{array}$ & $\begin{array}{l}0.70 \\
0.71\end{array}$ & $\begin{array}{l}0.37 \\
0.36\end{array}$ & $\begin{array}{l}0.32 \\
0.33\end{array}$ & $\begin{array}{l}0.81 \\
0.83\end{array}$ & $\begin{array}{l}0.81 \\
0.81\end{array}$ & $\begin{array}{l}097 \\
0.97\end{array}$ & $\begin{array}{l}0.97 \\
0.98\end{array}$ \\
\hline $\mathrm{D}$ & $\begin{array}{l}1.34 \\
1.33\end{array}$ & $\begin{array}{l}1.35 \\
1.35\end{array}$ & $\begin{array}{l}0.94 \\
0.94\end{array}$ & $\begin{array}{l}0.97 \\
0.97\end{array}$ & $\begin{array}{l}0.74 \\
0.73\end{array}$ & $\begin{array}{l}0.75 \\
0.76\end{array}$ & $\begin{array}{l}0.680 \\
0.690\end{array}$ & $\begin{array}{l}0.74 \\
0.75\end{array}$ & $\begin{array}{l}0.35 \\
0.36\end{array}$ & $\begin{array}{l}0.36 \\
0.37\end{array}$ & $\begin{array}{l}0.82 \\
0.82\end{array}$ & & $\begin{array}{l}0.96 \\
0.96\end{array}$ & $\begin{array}{l}0.99 \\
1.00\end{array}$ \\
\hline $\mathrm{E}$ & $\begin{array}{l}1.27 \\
1.26\end{array}$ & $\begin{array}{l}1.30 \\
1.30\end{array}$ & $\begin{array}{l}0.90 \\
0.92\end{array}$ & $\begin{array}{l}0.93 \\
0.94\end{array}$ & $\begin{array}{l}0.71 \\
0.72\end{array}$ & $\begin{array}{l}0.71 \\
0.72\end{array}$ & $\begin{array}{l}0.66 \\
0.67\end{array}$ & $\begin{array}{l}0.67 \\
0.65\end{array}$ & $\begin{array}{l}0.34 \\
0.34\end{array}$ & $\begin{array}{l}0.34 \\
0.35\end{array}$ & $\begin{array}{l}0.78 \\
0.78\end{array}$ & $\begin{array}{l}0.81 \\
0.80\end{array}$ & $\begin{array}{l}0.92 \\
0.92\end{array}$ & $\begin{array}{l}0.96 \\
0.95\end{array}$ \\
\hline $\mathrm{F}$ & $\begin{array}{l}1.29 \\
1.28\end{array}$ & $\begin{array}{l}1.30 \\
1.31\end{array}$ & $\begin{array}{l}0.92 \\
0.90\end{array}$ & $\begin{array}{l}0.94 \\
0.90\end{array}$ & $\begin{array}{l}0.74 \\
0.72\end{array}$ & $\begin{array}{l}0.78 \\
0.76\end{array}$ & $\begin{array}{l}0.66 \\
0.65\end{array}$ & $\begin{array}{l}0.69 \\
0.64\end{array}$ & $\begin{array}{l}0.40 \\
0.36\end{array}$ & $\begin{array}{l}0.39 \\
0.42\end{array}$ & $\begin{array}{l}0.75 \\
0.74\end{array}$ & $\begin{array}{l}0.81 \\
0.80\end{array}$ & $\begin{array}{l}0.94 \\
0.92\end{array}$ & $\begin{array}{l}0.93 \\
0.92\end{array}$ \\
\hline G & $\begin{array}{l}1.30 \\
1.30\end{array}$ & $\begin{array}{l}1.30 \\
1.32\end{array}$ & $\begin{array}{l}0.91 \\
0.94\end{array}$ & $\begin{array}{l}0.94 \\
0.92\end{array}$ & $\begin{array}{l}0.73 \\
0.73\end{array}$ & $\begin{array}{l}0.75 \\
0.74\end{array}$ & $\begin{array}{l}0.660 \\
0.660\end{array}$ & $\begin{array}{l}0.65 \\
0.65\end{array}$ & $\begin{array}{l}0.37 \\
0.37\end{array}$ & $\begin{array}{l}0.39 \\
0.40\end{array}$ & $\begin{array}{l}0.79 \\
0.76\end{array}$ & & $\begin{array}{l}0.96 \\
0.98\end{array}$ & $\begin{array}{l}0.94 \\
0.95\end{array}$ \\
\hline $\mathrm{H}$ & $\begin{array}{l}1.26 \\
1.28\end{array}$ & $\begin{array}{l}1.28 \\
1.29\end{array}$ & $\begin{array}{l}0.94 \\
0.91\end{array}$ & $\begin{array}{l}0.94 \\
0.94\end{array}$ & $\begin{array}{l}0.69 \\
0.69\end{array}$ & $\begin{array}{l}0.72 \\
0.73\end{array}$ & $\begin{array}{l}0.68 \\
0.68\end{array}$ & $\begin{array}{l}0.68 \\
0.70\end{array}$ & $\begin{array}{l}0.37 \\
0.37\end{array}$ & $\begin{array}{l}0.40 \\
0.40\end{array}$ & $\begin{array}{l}0.80 \\
0.77\end{array}$ & & $\begin{array}{l}0.98 \\
0.99\end{array}$ & $\begin{array}{l}1.02 \\
1.00\end{array}$ \\
\hline I & $\begin{array}{l}1.28 \\
1.32\end{array}$ & $\begin{array}{l}1.35 \\
1.32\end{array}$ & $\begin{array}{l}0.94 \\
0.92\end{array}$ & $\begin{array}{l}0.96 \\
0.95\end{array}$ & $\begin{array}{l}0.70 \\
0.70\end{array}$ & $\begin{array}{l}0.77 \\
0.74\end{array}$ & $\begin{array}{l}0.630 \\
0.62\end{array}$ & $\begin{array}{l}0.63 \\
0.63\end{array}$ & $\begin{array}{l}0.30 \\
0.32\end{array}$ & $\begin{array}{l}0.36 \\
0.38\end{array}$ & $\begin{array}{l}0.77 \\
0.78\end{array}$ & $\begin{array}{l}0.87 \\
0.83\end{array}$ & $\begin{array}{l}0.91 \\
0.92\end{array}$ & $\begin{array}{l}0.98 \\
0.95\end{array}$ \\
\hline$J$ & $\begin{array}{l}1.32 \\
1.32\end{array}$ & $\begin{array}{l}1.29 \\
1.32\end{array}$ & $\begin{array}{l}0.93 \\
0.96\end{array}$ & $\begin{array}{l}0.96 \\
0.99\end{array}$ & $\begin{array}{l}0.68 \\
0.71\end{array}$ & $\begin{array}{l}0.77 \\
0.74\end{array}$ & $\begin{array}{l}0.640 \\
0.68\end{array}$ & $\begin{array}{l}0.65 \\
0.66\end{array}$ & $\begin{array}{l}0.36 \\
0.35\end{array}$ & $\begin{array}{l}0.35 \\
0.35\end{array}$ & $\begin{array}{l}0.87 \\
0.82\end{array}$ & $\begin{array}{l}0.79 \\
0.80\end{array}$ & $\begin{array}{l}0.96 \\
0.96\end{array}$ & $\begin{array}{l}0.95 \\
0.96\end{array}$ \\
\hline $\mathrm{K}$ & $\begin{array}{l}1.26 \\
1.27\end{array}$ & $\begin{array}{l}1.25 \\
1.26\end{array}$ & $\begin{array}{l}0.90 \\
0.90\end{array}$ & $\begin{array}{l}0.91 \\
0.89\end{array}$ & $\begin{array}{l}0.68 \\
0.70\end{array}$ & $\begin{array}{l}0.71 \\
0.72\end{array}$ & $\begin{array}{l}0.610 \\
0.610\end{array}$ & $\begin{array}{l}0.61 \\
0.66\end{array}$ & $\begin{array}{l}0.32 \\
0.32\end{array}$ & $\begin{array}{l}0.33 \\
0.35\end{array}$ & $\begin{array}{l}0.78 \\
0.78\end{array}$ & $\begin{array}{l}0.78 \\
0.81\end{array}$ & $\begin{array}{l}0.92 \\
0.89\end{array}$ & $\begin{array}{l}0.90 \\
0.90\end{array}$ \\
\hline $\mathrm{L}$ & $\begin{array}{l}\text { 1. } 31 \\
1.27\end{array}$ & $\begin{array}{l}1.32 \\
1.26\end{array}$ & $\begin{array}{l}0.92 \\
0.93\end{array}$ & $\begin{array}{l}- \\
-\end{array}$ & $\begin{array}{l}0.68 \\
0.69\end{array}$ & - & $\begin{array}{l}0.68 \\
0.66\end{array}$ & - & $\begin{array}{l}0.27 \\
0.27\end{array}$ & - & $\begin{array}{l}0.81 \\
0.82\end{array}$ & - & $\begin{array}{l}1.00 \\
0.92\end{array}$ & $\overline{-}$ \\
\hline $\mathrm{M}$ & $\begin{array}{l}1.29 \\
1.29\end{array}$ & $\begin{array}{l}1.30 \\
1.37\end{array}$ & $\begin{array}{l}0.90 \\
0.90\end{array}$ & $\begin{array}{l}0.92 \\
0.94\end{array}$ & $\begin{array}{l}0.69 \\
0.70\end{array}$ & $\begin{array}{l}0.64 \\
0.64\end{array}$ & $\begin{array}{l}0.64 \\
0.68\end{array}$ & $\left.\begin{array}{l}0.51 \\
0.52\end{array}\right)$ & $\begin{array}{l}0.33 \\
0.34\end{array}$ & $\begin{array}{l}0.30 \\
0.34\end{array}$ & $\begin{array}{l}0.75 \\
0.75\end{array}$ & $\begin{array}{l}0.82 \\
0.82\end{array}$ & $\begin{array}{l}0.92 \\
0.93\end{array}$ & $\begin{array}{l}0.96 \\
0.95\end{array}$ \\
\hline $\mathrm{N}$ & $\begin{array}{l}1.31 \\
1.31\end{array}$ & $\begin{array}{l}1.29 \\
1.28\end{array}$ & $\begin{array}{l}1.01 \\
0.92\end{array}$ & $\begin{array}{l}0.93 \\
0.91\end{array}$ & $\begin{array}{l}0.74 \\
0.77\end{array}$ & $\begin{array}{l}0.67 \\
0.67\end{array}$ & $\begin{array}{l}0.710 \\
0.710\end{array}$ & $\begin{array}{l}0.68 \\
0.67\end{array}$ & $\begin{array}{l}0.35 \\
0.41\end{array}$ & $\begin{array}{l}0.30 \\
0.31\end{array}$ & $\begin{array}{l}0.82 \\
0.85\end{array}$ & $\begin{array}{l}0.80 \\
0.76\end{array}$ & $\begin{array}{l}0.94 \\
1.07\end{array}$ & $\begin{array}{l}0.94 \\
0.93\end{array}$ \\
\hline $\mathrm{O}$ & $\begin{array}{l}1.30 \\
1.31\end{array}$ & $\begin{array}{l}\text { 1. } 31 \\
1.33\end{array}$ & $\begin{array}{l}0.93 \\
0.94\end{array}$ & $\begin{array}{l}0.95 \\
0.94\end{array}$ & $\begin{array}{l}0.77 \\
0.77\end{array}$ & $\begin{array}{l}0.69 \\
0.66\end{array}$ & $\begin{array}{l}0.71 \\
0.69\end{array}$ & $\begin{array}{l}0.70 \\
0.67\end{array}$ & $\begin{array}{l}0.39 \\
0.40\end{array}$ & $\begin{array}{l}0.33 \\
0.30\end{array}$ & $\begin{array}{l}0.80 \\
0.81\end{array}$ & & $\begin{array}{l}0.96 \\
0.96\end{array}$ & $\begin{array}{l}0.95 \\
0.96\end{array}$ \\
\hline $\mathrm{P}$ & $\begin{array}{l}1.28 \\
1.26\end{array}$ & $\begin{array}{l}1.26 \\
1.26\end{array}$ & $\begin{array}{l}0.94 \\
0.95\end{array}$ & $\begin{array}{l}0.92 \\
0.90\end{array}$ & $\begin{array}{l}0.72 \\
0.69\end{array}$ & $\begin{array}{l}0.63 \\
0.58\end{array}$ & $\begin{array}{l}0.68 \\
0.67\end{array}$ & $\begin{array}{l}0.61 \\
0.63\end{array}$ & $\begin{array}{l}0.31 \\
0.29\end{array}$ & $\begin{array}{l}0.22 \\
0.21\end{array}$ & $\begin{array}{l}0.78 \\
0.77\end{array}$ & & $\begin{array}{l}0.95 \\
0.91\end{array}$ & $\begin{array}{l}0.90 \\
0.93\end{array}$ \\
\hline $\mathrm{Q}$ & $\begin{array}{l}1.28 \\
1.28\end{array}$ & $\begin{array}{l}1.28 \\
1.28\end{array}$ & $\begin{array}{l}0.89 \\
0.91\end{array}$ & $\begin{array}{l}0.89 \\
0.91\end{array}$ & $\left(\begin{array}{l}0.40 \\
0.45\end{array}\right)$ & $\left(\begin{array}{l}0.35 \\
0.27\end{array}\right)$ & $\begin{array}{l}0.56 \\
0.58\end{array}$ & $\begin{array}{l}0.65 \\
0.66\end{array}$ & $\left(\begin{array}{l}0.15 \\
0.14\end{array}\right)$. & $\left(\begin{array}{l}0.15 \\
0.15\end{array}\right)$ & $\begin{array}{l}0.74 \\
0.74\end{array}$ & $\begin{array}{l}0.73 \\
0.73\end{array}$ & $\begin{array}{l}0.88 \\
0.91\end{array}$ & $\begin{array}{l}0.87 \\
0.87\end{array}$ \\
\hline Av. & 1.29 & 1.30 & 0.92 & 0.93 & 0.70 & 0.68 & 0.660 & 0.66 & 0.33 & 0.32 & 0.79 & 0.80 & 0.94 & 0.94 \\
\hline Max. & 1.34 & 1.37 & 1.01 & 0.99 & 0.77 & 0.78 & 0.740 & 0.75 & 0.41 & 0.42 & 0.87 & 0.87 & 1.07 & 1.02 \\
\hline Min. & 1.19 & 1.25 & 0.89 & 0.89 & 0.40 & 0.27 & 0.560 & 0.51 & 0.14 & 0.15 & 0.74 & 0.73 & 0.88 & 0.87 \\
\hline
\end{tabular}

元配置の分散分析を行ない，所間ならびに所内精度を 次式により算出し一覧表にし Table 5 に示した。

$$
\begin{array}{ll}
\text { 所内精度 } & \sigma_{w}=\sqrt{\sigma_{E}^{2}}=\sqrt{V_{E}} \\
\text { 所間準精度 } & \sigma_{b}=\sqrt{\sigma_{x}^{2}+\sigma_{E}^{2} / 2}=\sqrt{\left(V_{L}+V_{E}\right) / 2} \\
\text { 所間精度 } & \sigma_{\bar{x}}=\sqrt{\sigma_{b}^{2}+\sigma_{E}^{2} / 2}
\end{array}
$$

Table 5 より，全体として所内和よび所間精度のも っともよい方法はガス化法であった。セミミクロケル ダール法は, 試料の種類により分析精度が異なる傾向
がある。この傾向は分解触媒であるセレンを用いない 方がより大きい。機器分析法は, 所内拈よび所間精度 ともにもっとも悪い結果が出ているが，これは機器分 析法が相対法であるにもかかわらず，今回の協同実験 に打いては，いかなる条件の規制も行なわなかったた めと考光られる。

\section{3 分析方法間のカタョリ}

異常值を含んだすべ゙ての定量值を用い，セミミクロ 
Table 3 Observed values by Semi-Micro gasification method

\begin{tabular}{|c|c|c|c|c|c|c|c|}
\hline $\begin{array}{c}\text { Sample } \\
\text { Lab. }\end{array}$ & No. 1 & 2 & 3 & 4 & 5 & 6 & 7 \\
\hline $\mathrm{A}$ & $\begin{array}{l}1.30 \\
1.35\end{array}$ & $\begin{array}{l}0.96 \\
0.96\end{array}$ & $\begin{array}{l}0.79 \\
0.78\end{array}$ & $\left(\begin{array}{l}0.81 \\
0.80\end{array}\right)$ & $\begin{array}{l}0.35 \\
0.40\end{array}$ & $\begin{array}{l}0.90 \\
0.85\end{array}$ & $\begin{array}{l}0.97 \\
0.96\end{array}$ \\
\hline B & $\begin{array}{l}1.32 \\
1.32\end{array}$ & $\begin{array}{l}0.98 \\
0.98\end{array}$ & $\begin{array}{l}0.82 \\
0.81\end{array}$ & $\begin{array}{l}0.74 \\
0.76\end{array}$ & $\begin{array}{l}0.43 \\
0.43\end{array}$ & $\begin{array}{l}0.85 \\
0.85\end{array}$ & $\begin{array}{l}0.99 \\
1.00\end{array}$ \\
\hline $\mathrm{C}$ & $\begin{array}{l}1.33 \\
1.33\end{array}$ & $\begin{array}{l}0.96 \\
0.98\end{array}$ & $\begin{array}{l}0.81 \\
0.82\end{array}$ & $\begin{array}{l}0.76 \\
0.77\end{array}$ & $\begin{array}{l}0.39 \\
0.42\end{array}$ & $\begin{array}{l}0.82 \\
0.85\end{array}$ & $\begin{array}{l}0.93 \\
0.98\end{array}$ \\
\hline $\mathrm{D}$ & $\begin{array}{l}1.29 \\
1.30\end{array}$ & $\begin{array}{l}0.95 \\
0.96\end{array}$ & $\begin{array}{l}0.78 \\
0.78\end{array}$ & $\begin{array}{l}0.72 \\
0.75\end{array}$ & $\begin{array}{l}0.37 \\
0.39\end{array}$ & $\begin{array}{l}0.81 \\
0.82\end{array}$ & $\begin{array}{l}0.94 \\
0.95\end{array}$ \\
\hline $\mathrm{E}$ & $\left.\begin{array}{l}1.26 \\
1.25\end{array}\right)$ & $\begin{array}{l}0.94 \\
0.91\end{array}$ & $\begin{array}{l}0.73 \\
0.77\end{array}$ & $\begin{array}{l}0.72 \\
0.72\end{array}$ & $\begin{array}{l}0.41 \\
0.37\end{array}$ & $\begin{array}{l}0.81 \\
0.79\end{array}$ & $\begin{array}{l}0.97 \\
0.92\end{array}$ \\
\hline $\mathrm{F}$ & $\begin{array}{l}1.36 \\
1.35\end{array}$ & $\begin{array}{l}1.00 \\
0.98\end{array}$ & $\begin{array}{l}0.83 \\
0.81\end{array}$ & $\begin{array}{l}0.77 \\
0.77\end{array}$ & $\begin{array}{l}0.40 \\
0.41\end{array}$ & $\begin{array}{l}0.86 \\
0.85\end{array}$ & $\begin{array}{l}1.00 \\
0.99\end{array}$ \\
\hline $\mathrm{G}$ & $\begin{array}{l}1.30 \\
1.32\end{array}$ & $\begin{array}{l}0.97 \\
0.96\end{array}$ & $\begin{array}{l}0.77 \\
0.74\end{array}$ & $\begin{array}{l}0.73 \\
0.74\end{array}$ & $\begin{array}{l}0.38 \\
0.38\end{array}$ & $\begin{array}{l}0.83 \\
0.80\end{array}$ & $\begin{array}{l}0.95 \\
0.95\end{array}$ \\
\hline $\mathrm{H}$ & $\begin{array}{l}1.30 \\
1.32\end{array}$ & $\begin{array}{l}0.97 \\
0.98\end{array}$ & $\begin{array}{l}0.78 \\
0.79\end{array}$ & $\begin{array}{l}0.73 \\
0.76\end{array}$ & $\left(\begin{array}{l}0.44 \\
0.45\end{array}\right)$ & $\begin{array}{l}0.84 \\
0.84\end{array}$ & $\begin{array}{l}0.96 \\
0.99\end{array}$ \\
\hline I & $\begin{array}{l}1.29 \\
1.26\end{array}$ & $\begin{array}{l}0.93 \\
0.93\end{array}$ & $\begin{array}{l}0.76 \\
0.75\end{array}$ & $\begin{array}{l}0.74 \\
0.73\end{array}$ & $\left(\begin{array}{l}0.34 \\
0.35\end{array}\right)$ & $\begin{array}{l}0.77 \\
0.79\end{array}$ & $\begin{array}{l}0.91 \\
0.88\end{array}$ \\
\hline Av. & 1.31 & 0.96 & 0.79 & c. 75 & 0.40 & 0.83 & 0.96 \\
\hline Max. & 1.36 & 1.00 & 0.83 & 0.81 & 0.45 & 0.90 & 1.00 \\
\hline Min. & 1.25 & 0.93 & 0.73 & 0.72 & 0.34 & 0.77 & 0.88 \\
\hline
\end{tabular}

): Outliers

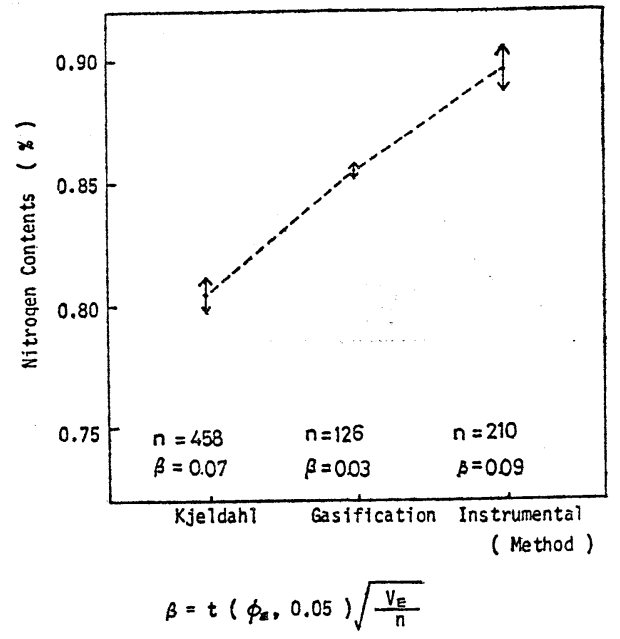

Fig. 1 Mean values and confidence interval of each method

ケルダール法については, 分析所, 試料の種類, セレ ンの使用の有無を因子とした三元配置の分散分析を行 ない，案たセミミクロガス化法扣よび機器分析法につ いては, 分析所, 試料の種類を 2 因子とした二元配置
の分散分析を行なった。この結果，セレンの使用の有 無については，母平均間に有意差は認められなかっ た。方法間のカタヨリについて, 分析所内の不偏分散 $\left(V_{E}\right)$ を用い，それぞれの方法についての母平均の 信頼区間を信頼率 95\% で求めたのが，Fig.1 で㐫 る。

この結果, 全平均值は機器法, ガス化法, ケルダー ル法の順に小さくなること, 分析精度はガス化法, ケ ルダール法, 機器法の順に悪くなることが示された。

次に，試料ごとの傾向について，異常值を除いた場 合の定量值の全平均值および信頼区間を求め, Fig. 2 とした。この結果, セミミクロケルダール法でのセレ ン触媒の使用は，定量值に影響を及ぼしていないこ 之, 全平均值が, 機器法, ガス化法, ケルダール法の 順に小さくなる傾向は、 コークスの種類により異なる ことなどがわかった。すなわち，試料 No.1 の鋳物用 コークスでは，方法による定量值に差がみられないの に反し, 試料 No. 5 の高炉解体コークス（高温部）な ぞは, セミミクロケルダール法での值が, 機器分析法 での值の $60 \%$ 程度になっている。

$3.4 \mathrm{~L}_{\mathrm{C}}$ 值と定量值との関係 
Table 4 Observed values by instrumental analysis

$(\%)$

\begin{tabular}{|c|c|c|c|c|c|c|c|c|c|}
\hline $\begin{array}{l}\text { Sample No. } \\
\text { Lab. }\end{array}$ & 1 & 2 & 3 & 4 & 5 & 6 & 7 & \multicolumn{2}{|c|}{ Conditions } \\
\hline A & $\begin{array}{l}1.27 \\
1.26\end{array}$ & $\begin{array}{l}1.03 \\
1.08\end{array}$ & $\begin{array}{l}0.81 \\
0.82\end{array}$ & $\begin{array}{l}0.70 \\
0.65\end{array}$ & $\begin{array}{l}0.67 \\
0.70\end{array}$ & $\begin{array}{l}1.04 \\
0.97\end{array}$ & $\begin{array}{l}1.09 \\
1.10\end{array}$ & $\begin{array}{l}* \mathrm{~T} . \mathrm{C} . \\
250 \mu \mathrm{m}\end{array}$ & $\begin{array}{c}1100^{\circ} \mathrm{C} \\
3 \mathrm{mg}\end{array}$ \\
\hline B & $\left(\begin{array}{l}0.65 \\
0.61\end{array}\right)$ & $\left.\begin{array}{l}0.66 \\
0.63\end{array}\right)$ & $\left.\begin{array}{l}0.56 \\
0.56\end{array}\right)$ & $\left(\begin{array}{l}0.34 \\
0.35\end{array}\right)$ & $\left(\begin{array}{l}0.37 \\
0.40\end{array}\right)$ & $\left(\begin{array}{l}0.61 \\
0.66\end{array}\right)$ & $\left.\begin{array}{l}0.57 \\
0.49\end{array}\right)$ & $\begin{array}{l}\text { T.C. } \\
250 \mu \mathrm{m}\end{array}$ & $\begin{array}{l}850^{\circ} \mathrm{C} \\
2 \mathrm{mg}\end{array}$ \\
\hline $\mathrm{C}$ & $\begin{array}{l}1.21 \\
1.24\end{array}$ & $\begin{array}{l}0.92 \\
0.89\end{array}$ & $\begin{array}{l}0.63 \\
0.62\end{array}$ & $\begin{array}{l}0.65 \\
0.67\end{array}$ & $\begin{array}{l}0.50 \\
0.49\end{array}$ & $\begin{array}{l}0.76 \\
0.79\end{array}$ & $\begin{array}{l}0.97 \\
0.94\end{array}$ & $\begin{array}{l}* * \mathrm{~V} . \mathrm{T} . \\
149 \mu \mathrm{m}\end{array}$ & $\begin{array}{l}900^{\circ} \mathrm{C} \\
100 \mathrm{mg}\end{array}$ \\
\hline $\mathrm{D}$ & $\begin{array}{l}1.33 \\
1.32\end{array}$ & $\begin{array}{l}1.09 \\
1.07\end{array}$ & $\begin{array}{l}0.85 \\
0.85\end{array}$ & $\begin{array}{l}0.80 \\
0.81\end{array}$ & $\begin{array}{l}0.55 \\
0.53\end{array}$ & $\begin{array}{l}0.94 \\
0.92\end{array}$ & $\begin{array}{l}1.10 \\
1.07\end{array}$ & $\begin{array}{l}\text { T. C. } \\
250 \mu \mathrm{m}\end{array}$ & $\begin{array}{l}950^{\circ} \mathrm{C} \\
200 \mathrm{mg}\end{array}$ \\
\hline$E$ & $\begin{array}{l}1.26 \\
1.30\end{array}$ & $\begin{array}{l}1.04 \\
1.06\end{array}$ & $\begin{array}{l}0.84 \\
0.86\end{array}$ & $\begin{array}{l}0.78 \\
0.76\end{array}$ & $\begin{array}{l}0.52 \\
0.53\end{array}$ & $\begin{array}{l}0.89 \\
0.90\end{array}$ & $\begin{array}{l}1.05 \\
1.04\end{array}$ & $\begin{array}{l}\text { T.C. . } \\
250 \mu \mathrm{m}\end{array}$ & $\begin{array}{l}900^{\circ} \mathrm{C} \\
140 \mathrm{mg}\end{array}$ \\
\hline $\mathrm{F}$ & $\begin{array}{l}1.17 \\
1.26\end{array}$ & $\begin{array}{l}1.00 \\
1.05\end{array}$ & $\begin{array}{l}0.76 \\
0.82\end{array}$ & $\begin{array}{l}0.69 \\
0.76\end{array}$ & $\begin{array}{l}0.51 \\
0.58\end{array}$ & $\begin{array}{l}0.85 \\
0.89\end{array}$ & $\begin{array}{l}0.98 \\
1.02\end{array}$ & $\begin{array}{l}\text { T. C. } \\
250 \mu \mathrm{m}\end{array}$ & $\begin{array}{l}900^{\circ} \mathrm{C} \\
100 \mathrm{mg}\end{array}$ \\
\hline G & $\left(\begin{array}{l}1.01 \\
0.96\end{array}\right)$ & $\begin{array}{l}0.78 \\
0.83\end{array}$ & $\begin{array}{l}0.85 \\
0.86\end{array}$ & $\begin{array}{l}0.78 \\
0.76\end{array}$ & $\begin{array}{l}0.45 \\
0.42\end{array}$ & $\begin{array}{l}0.73 \\
0.74\end{array}$ & $\begin{array}{l}0.86 \\
0.90\end{array}$ & $\begin{array}{l}\mathrm{V} . \mathrm{T} . \\
149 \mu \mathrm{m}\end{array}$ & $\begin{array}{l}950^{\circ} \mathrm{C} \\
60 \mathrm{mg}\end{array}$ \\
\hline $\mathrm{H}$ & $\left.\begin{array}{l}1.54 \\
1.60\end{array}\right)$ & $\left.\begin{array}{l}1.40 \\
1.29\end{array}\right)$ & $\left.\begin{array}{l}1.00 \\
1.04\end{array}\right)$ & $\left(\begin{array}{l}0.93 \\
0.93\end{array}\right)$ & $\left(\begin{array}{l}0.74 \\
0.68\end{array}\right)$ & $\left.\begin{array}{l}1.13 \\
1.12\end{array}\right)$ & $\left.\begin{array}{l}1.23 \\
1.28\end{array}\right)$ & $\begin{array}{l}\text { T.C. } \\
74 \mu \mathrm{m}\end{array}$ & $\begin{array}{l}950^{\circ} \mathrm{C} \\
1.5 \mathrm{mg}\end{array}$ \\
\hline I & $\begin{array}{l}1.36 \\
1.36\end{array}$ & $\begin{array}{l}1.10 \\
1.13\end{array}$ & $\begin{array}{l}0.89 \\
0.90\end{array}$ & $\begin{array}{l}0.81 \\
0.83\end{array}$ & $\begin{array}{l}0.58 \\
0.60\end{array}$ & $\begin{array}{l}0.98 \\
1.01\end{array}$ & $\begin{array}{l}1.12 \\
1.15\end{array}$ & $\begin{array}{l}\text { T. C. } \\
250 \mu \mathrm{m}\end{array}$ & $\begin{array}{l}1000^{\circ} \mathrm{C} \\
300 \mathrm{mg}\end{array}$ \\
\hline J & $\begin{array}{l}1.31 \\
1.29\end{array}$ & $\begin{array}{l}1.03 \\
1.07\end{array}$ & $\begin{array}{l}0.83 \\
0.81\end{array}$ & $\begin{array}{l}0.74 \\
0.75\end{array}$ & $\begin{array}{l}0.54 \\
0.52\end{array}$ & $\begin{array}{l}0.88 \\
0.87\end{array}$ & $\begin{array}{l}1.05 \\
1.07\end{array}$ & $\begin{array}{l}\text { T. C. } \\
250 \mu \mathrm{m}\end{array}$ & $\begin{array}{l}950^{\circ} \mathrm{C} \\
100 \mathrm{mg}\end{array}$ \\
\hline $\mathrm{K}$ & $\begin{array}{l}1.33 \\
1.31\end{array}$ & $\begin{array}{l}1.06 \\
1.03\end{array}$ & $\begin{array}{l}0.85 \\
0.84\end{array}$ & $\begin{array}{l}0.81 \\
0.79\end{array}$ & $\begin{array}{l}0.55 \\
0.57\end{array}$ & $\begin{array}{l}0.89 \\
0.87\end{array}$ & $\begin{array}{l}0.99 \\
1.01\end{array}$ & $\begin{array}{l}\text { T.C. } \\
250 \mu \mathrm{m}\end{array}$ & $\begin{array}{l}950^{\circ} \mathrm{C} \\
100 \mathrm{mg}\end{array}$ \\
\hline L & $\begin{array}{l}1.40 \\
1.45\end{array}$ & $\begin{array}{l}1.15 \\
1.15\end{array}$ & $\begin{array}{l}0.88 \\
0.90\end{array}$ & $\begin{array}{l}0.81 \\
0.83\end{array}$ & $\begin{array}{l}0.50 \\
0.55\end{array}$ & $\begin{array}{l}0.91 \\
0.92\end{array}$ & $\begin{array}{l}1.07 \\
1.13\end{array}$ & $\begin{array}{l}\text { T.C. } \\
149 \mu \mathrm{m}\end{array}$ & $\begin{array}{l}1000^{\circ} \mathrm{C} \\
130 \mathrm{mg}\end{array}$ \\
\hline M & $\begin{array}{l}1.30 \\
1.20\end{array}$ & $\begin{array}{l}1.10 \\
1.01\end{array}$ & $\begin{array}{l}0.84 \\
0.82\end{array}$ & $\begin{array}{l}0.71 \\
0.79\end{array}$ & $\begin{array}{l}0.57 \\
0.62\end{array}$ & $\begin{array}{l}0.99 \\
1.01\end{array}$ & $\begin{array}{l}1.17 \\
1.17\end{array}$ & $\begin{array}{l}\mathrm{V} . \mathrm{T} . \\
250 \mu \mathrm{m}\end{array}$ & $\begin{array}{c}1050^{\circ} \mathrm{C} \\
80 \mathrm{mg}\end{array}$ \\
\hline $\mathrm{N}$ & $\begin{array}{l}1.32 \\
1.33\end{array}$ & $\begin{array}{l}1.09 \\
1.11\end{array}$ & $\begin{array}{l}0.86 \\
0.87\end{array}$ & $\begin{array}{l}0.80 \\
0.81\end{array}$ & $\begin{array}{l}0.52 \\
0.53\end{array}$ & $\begin{array}{l}0.92 \\
0.91\end{array}$ & $\begin{array}{l}1.06 \\
1.06\end{array}$ & $\begin{array}{l}\text { T.C. } \\
250 \mu \mathrm{m}\end{array}$ & $\begin{array}{l}980^{\circ} \mathrm{C} \\
150 \mathrm{mg}\end{array}$ \\
\hline $\mathrm{O}$ & $\begin{array}{l}1.25 \\
1.24\end{array}$ & $\begin{array}{l}0.81 \\
0.82\end{array}$ & $\begin{array}{l}0.68 \\
0.68\end{array}$ & $\begin{array}{l}0.67 \\
0.68\end{array}$ & $\begin{array}{l}0.52 \\
0.54\end{array}$ & $\begin{array}{l}0.80 \\
0.82\end{array}$ & $\begin{array}{l}0.96 \\
0.97\end{array}$ & $\begin{array}{l}\mathrm{V} \cdot \mathrm{T} . \\
250 \mu \mathrm{m}\end{array}$ & $\begin{array}{l}980^{\circ} \mathrm{C} \\
100 \mathrm{mg}\end{array}$ \\
\hline Av. & 1.25 & 1.02 & 0.81 & 0.74 & 0.55 & 0.89 & 1.02 & & \\
\hline Max. & 1.60 & 1.40 & 1.04 & 0.93 & 0.74 & 1.13 & 1.28 & & \\
\hline Min. & 0.61 & 0.63 & 0.56 & 0.34 & 0.37 & 0.61 & 0.49 & & \\
\hline
\end{tabular}

* Thermal conductivity method

** Volumetric techniques ); Outliers

Fig. 2 に示された，分析方法間のカタョリの程度 功，コークスの種類により異なっているのは，コーク スのグラファイト化の程度と関係していることが考光 られる。そこで, これらのコークスの炭素の結晶子の 大きさを知るために， $\mathrm{X}$ 線回析法により $\mathrm{L}_{C}$ 值を求 めた。（測定は，学振第 117 委員会の方法に準哆）従 来, コークスの $\mathrm{L}_{C}$ 值は履歴温度に比例することが 知られて抢り ${ }^{3)}$, コークスの $\mathrm{L}_{C}$ 值を求めて高炉の炉 内温度を推定することがしばしば行なわれている。今 回の協同実験に 用いた 7 種類 のコークスの $\mathrm{L}_{C}$ 値を 測定し, Table 6 亿示した。な拉, 履歴温度と $\mathrm{L}_{C}$ 值
の関倸は，Fig.3 のようである。

この結果, 分析方法間のカタヨリのもっとも大きか った高炉解体コークスの高温部のものは, $\mathrm{L}_{C}$ 值が $32.7 \AA ̊$ と一番大きく, 他のコークスに比ベグラファ イト化が進行していることがわかる。履歴温度だけが 異なると考えられる 3 種類の高炉解体コークス（試料 No.5，6，7）について Fig.2 をみると，グラファイ 卜化が進行している順に, 全平均值が機器法, ガス化 法, ケルダール法の順に小さくなる傾向が著しくなっ ている。この原因としては，グラファイト化が進むに つれて,ケルダール法では分解が困難な形態の窒素が 
Table 5 Results of statisitical analysis

(1) Semi-micro Kjeldahl-.-Se

Including Outliers Excluding Outliers

\begin{tabular}{lcccccccccc}
\hline Cokes & $n$ & $\overline{\bar{x}}$ & $* \sigma_{w}$ & $* * \sigma_{b}$ & $* * * \sigma_{\bar{x}}$ & $n$ & $\overline{\bar{x}}$ & $* \sigma_{w}$ & $* * \sigma_{b}$ & $* * * \sigma_{\bar{x}}$ \\
\hline 1 Foundry & 17 & 1.291 & 0.0155 & 0.0269 & 0.0291 & 17 & 1.291 & 0.0155 & 0.0269 & 0.0291 \\
Metallurgical & 17 & 0.924 & 0.0184 & 0.0159 & 0.0211 & 17 & 0.924 & 0.0184 & 0.0159 & 0.0211 \\
1 (L. V. Coal) & 17 & 0.695 & 0.0146 & 0.0777 & 0.0784 & 15 & 0.718 & 0.0120 & 0.0254 & 0.0268 \\
2. H. Coal) & 17 & 0.662 & 0.0121 & 0.0437 & 0.0456 & 17 & 0.662 & 0.0121 & 0.0437 & 0.0456 \\
D. B. F. (Bosh) & 17 & 0.326 & 0.0144 & 0.0646 & 0.0654 & 15 & 0.345 & 0.0148 & 0.0327 & 0.0344 \\
D. B.F. (Lower) & 17 & 0.790 & 0.0138 & 0.0305 & 0.0321 & 17 & 0.790 & 0.0138 & 0.0306 & 0.0321 \\
D.B.F. (Upper) & 17 & 0.944 & 0.0318 & 0.0206 & 0.0305 & 17 & 0.944 & 0.0318 & 0.0206 & 0.0305 \\
\hline
\end{tabular}

(2) Semi-micro Kjeldahl

\begin{tabular}{lcccccccccc}
\hline Cokes & $n$ & $\bar{x}$ & $* \sigma_{w}$ & $* * \sigma_{b}$ & $* * * \sigma_{\bar{x}}$ & $n$ & $\overline{\bar{x}}$ & $* \sigma_{w}$ & $* * \sigma_{b}$ & $* * * \sigma_{\bar{x}}$ \\
\hline Foundry & 17 & 1.302 & 0.0188 & 0.0246 & 0.0280 & 17 & 1.302 & 0.0188 & 0.0246 & 0.0280 \\
Metallurgical & 16 & 0.931 & 0.0148 & 0.0216 & 0.0240 & 16 & 0.931 & 0.0148 & 0.0216 & 0.0240 \\
I (L. V. Coal) & 16 & 0.675 & 0.0378 & 0.1098 & 0.1123 & 15 & 0.700 & 0.0318 & 0.0534 & 0.0579 \\
2 (H. V. Coal) & 16 & 0.658 & 0.0168 & 0.0523 & 0.0536 & 15 & 0.667 & 0.0172 & 0.0372 & 0.0392 \\
D.B.F. (Bosh) & 16 & 0.321 & 0.0128 & 0.0726 & 0.0732 & 15 & 0.332 & 0.0132 & 0.0516 & 0.0594 \\
D.B.F. (Lower) & 16 & 0.804 & 0.0132 & 0.0291 & 0.0305 & 16 & 0.804 & 0.0132 & 0.0291 & 0.0305 \\
D.B.F. (Upper) & 16 & 0.944 & 0.0100 & 0.0336 & 0.0351 & 16 & 0.944 & 0.0100 & 0.0336 & 0.0351 \\
\hline
\end{tabular}

(3) Semi-micro Gasification

\begin{tabular}{lcccccccccc}
\hline \multicolumn{1}{c}{ Cokes } & $n$ & $\overline{\bar{x}}$ & $* \sigma_{w}$ & $* * \sigma_{b}$ & $* * * \sigma_{\bar{x}}$ & $n$ & $\overline{\bar{x}}$ & $* \sigma_{w}$ & $* * \sigma_{b}$ & $* * * \sigma_{\bar{x}}$ \\
\hline Foundry & 9 & 1.308 & 0.0158 & 0.0278 & 0.0300 & 7 & 1.309 & 0.0175 & 0.0144 & 0.0190 \\
Metallurgical & 9 & 0.961 & 0.0105 & 0.0204 & 0.0218 & 9 & 0.961 & 0.0105 & 0.0204 & 0.0218 \\
1 (L. V. Coal) & 9 & 0.784 & 0.0137 & 0.0258 & 0.0275 & 9 & 0.784 & 0.0137 & 0.0258 & 0.0275 \\
2. (H. V. Coal) & 9 & 0.751 & 0.0102 & 0.0241 & 0.0256 & 8 & 0.744 & 0.0125 & 0.0143 & 0.0168 \\
D. B.F. (Bosh) & 9 & 0.395 & 0.0178 & 0.0275 & 0.0302 & 7 & 0.395 & 0.0198 & 0.0137 & 0.0196 \\
D.B.F. (Lower) & 9 & 0.829 & 0.0172 & 0.0270 & 0.0296 & 9 & 0.829 & 0.0172 & 0.0270 & 0.0296 \\
D.B.F. (Upper) & 9 & 0.958 & 0.0200 & 0.0271 & 0.0305 & 9 & 0.958 & 0.0200 & 0.0271 & 0.0305 \\
\hline
\end{tabular}

(4) Instrumental Analysis

\begin{tabular}{lcccccccccc}
\hline Cokes & $n$ & $\overline{\bar{x}}$ & $* \sigma_{w}$ & $* * \sigma_{b}$ & $* * * \sigma_{\bar{x}}$ & $n$ & $\overline{\bar{x}}$ & $* \sigma_{w}$ & $* * \sigma_{b}$ & $* * * \sigma_{\bar{x}}$ \\
\hline Foundry & 15 & 1.248 & 0.0327 & 0.0625 & 0.0666 & 12 & 1.295 & 0.0318 & 0.0607 & 0.0607 \\
Metallugical & 15 & 1.016 & 0.0338 & 0.1647 & 0.1665 & 13 & 1.019 & 0.0283 & 0.1067 & 0.1086 \\
1 (L. V. Coal) & 15 & 0.813 & 0.0157 & 0.1134 & 0.1139 & 13 & 0.816 & 0.0149 & 0.0782 & 0.0782 \\
2. (H. V. Coal) & 15 & 0.740 & 0.0236 & 0.1282 & 0.1293 & 13 & 0.755 & 0.0253 & 0.0540 & 0.0568 \\
D. B.F. (Bosh) & 15 & 0.545 & 0.0248 & 0.0813 & 0.0817 & 13 & 0.545 & 0.0232 & 0.0558 & 0.0582 \\
D. B. F. (Lower) & 15 & 0.891 & 0.0208 & 0.1037 & 0.1207 & 13 & 0.892 & 0.0200 & 0.0822 & 0.0834 \\
D. B. F. (Upper) & 15 & 1.022 & 0.0255 & 0.1635 & 0.1645 & 13 & 1.042 & 0.0202 & 0.0788 & 0.0801 \\
\hline
\end{tabular}

* $\sigma_{w} ;$ Repeatability

** $\sigma_{b}=\sqrt{\sigma_{\bar{x}}^{2}+\sigma_{w}^{2} / 2}$

$* * * \sigma_{\bar{x}} ;$ Reproducibility

できるのか，炭素質の分解に長時間を要するために， 窒素分の損失が起こるかのいずれか，あるいは両者が 考えられる。機器法とガス化法との定量值の差につい ては, 窒素の形態に問題があるのか, 機器分析の際に 試料に吸着された窒素やあるいは他のガスを測定した ためなのか明らかでない。
$\mathrm{L}_{C}$ 值が分析所間精度に 影響を及ぽしているかどう かを調べるために，搞の括のデータについてグラフ化 して調ベた結果，七ミミクロケルダール法の全デー タを使用した場合に， $\mathrm{L}_{C}$ 值が大きくなる程分析精度 $\left(\sigma_{\bar{x}}\right)$ が悪くなる傾向がみられた。この結果を Fig.4 に示す。異常値を除いた場合に同様の図を描くとこの 
Table $6 \quad L_{C}(\AA)$ Values and the heat treated temperature of cokes

\begin{tabular}{clr}
\hline No. & \multicolumn{1}{c}{ Cokes } & $\mathrm{L}_{\mathrm{C}}(\AA)$ \\
\hline 1 & Foundry Coke & 15.7 \\
2 & Metallurgical Coke & 15.1 \\
3 & Coke 1 (U. S., L. V. Coal) & 21.5 \\
4 & Coke 2 (U. S., H. V. Coal) & 13.6 \\
5 & $*$ Dissected B. F. Coke (Bosh) & 32.7 \\
6 & Dissected B.F. Coke (Lower Shaft) & 16.4 \\
7 & Dissected B.F. Coke (Upper Shaft) & 14.9 \\
\hline
\end{tabular}

* Samples were taken from dissected blast furnace after shut down.

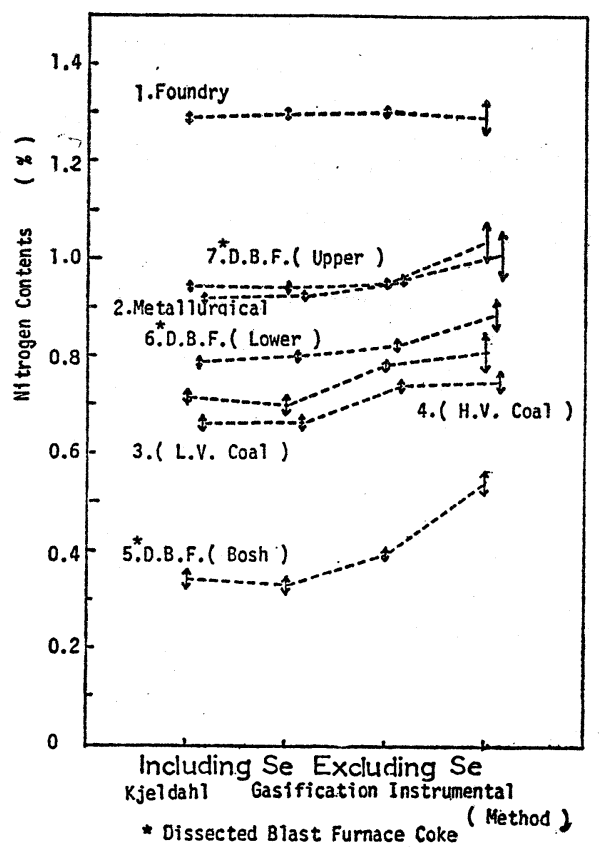

Fig. 2 Comparison of the observed values by each method

傾向はほとんど無くなってしまう。このことは，七ミ ミクロケルダール法の場合, グラファイト化が進んだ 試料は分解が困難であるため, 分解が不十分となり分 析値のバラツキの 原因となっていることを示してい る。な扔，機器分析法拉よびセミミクロガス化法で は，このような傾向はみられない。

3.5 セミミクロケルダール法での 分解時間と定量 值との関係

セミミクロケルダール法での硫酸分解に要した時間 と, 定量值との関倸を調べた。グラファイト化が一番

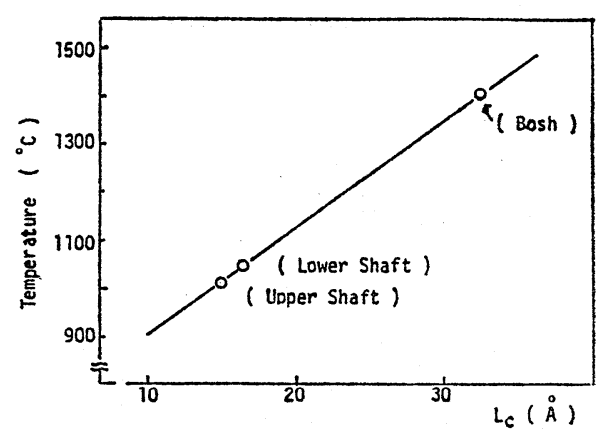

Fig. 3 Relationship between $L_{C}(\AA)$ and heat treated temperature of dissected blast furnace cokes

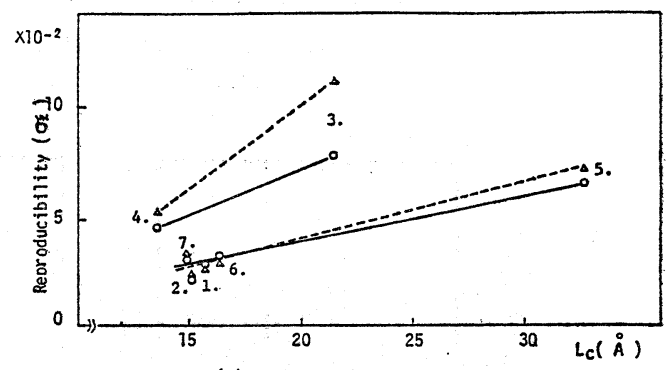

(1) Includina Outliers

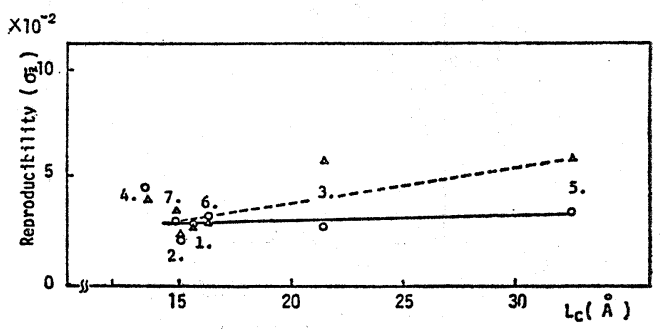

(2) Excludina Outliers

Using Catalyst Mixture Excludina Se $\infty$ Using Catalyst Mixture Includina Se

1. Foundry Coke

2. Metallurgical Coke

ï 3. Coke 1. (U.S., L.v. Coal)

4. Coke 2. (U.S.,H.v. Coal)

. Dissected Blast Furnace Coke (Bosh) . Dissected Blast Furnace Coke (Lower Shaft) 7. D1ssected Blast Furnace Coke (Upper Shaft)

Fig. 4 Relationship between $L_{C}(\AA)$ and reproducibility $\left(\sigma_{\bar{x}}\right)$ in Semi-micro Kjeldahl method

進んでいると考えられる試料 No. 5 の高炉解体コーク ス（高温部）と，グラファイト化の進んでいないNo.1 の鋳物用ニークスについてのグラフを示すと, Fig., , 6のようになる。この結果, グラファイト化の進んで いる試料 No. 5 では, 分解触媒であるセレンを用いた 場合と用いない場合では分解に要する時間が 2 倍以上 違う。また ISO で問題となっているセレン触媒を使 


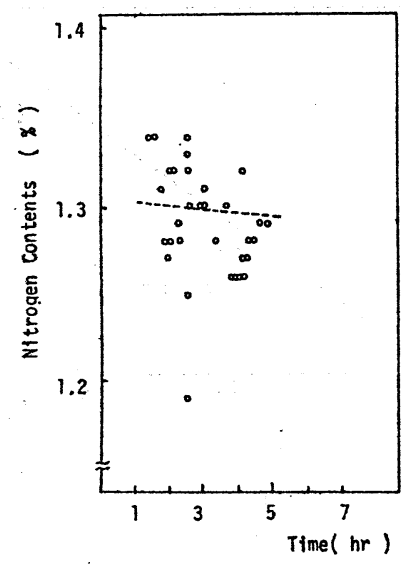

(1) Using Catalyst Mixtur Including Se

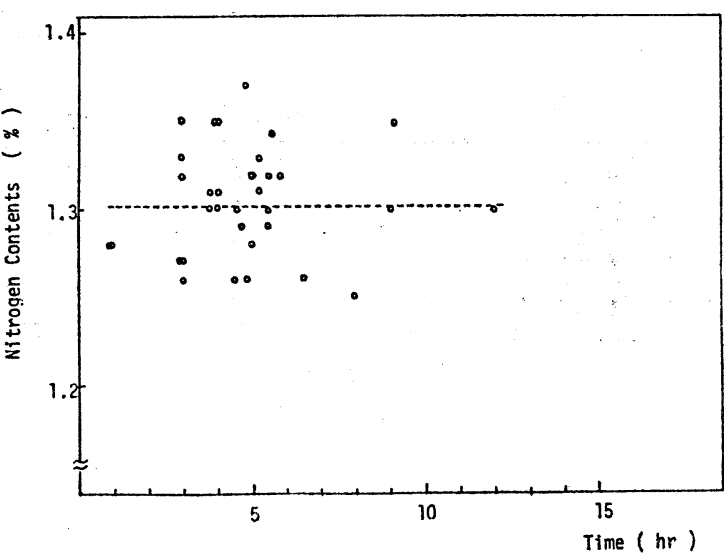

(2) Using Catalvst Mixtur Excluding Se

Fig. 5 Relationship between observed values and using time of acid digestion sample-- No. 1 Foundry coke

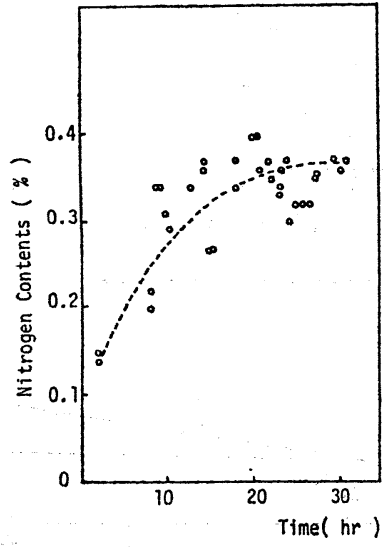

(1) Using Catalyst. Mixture Including Se

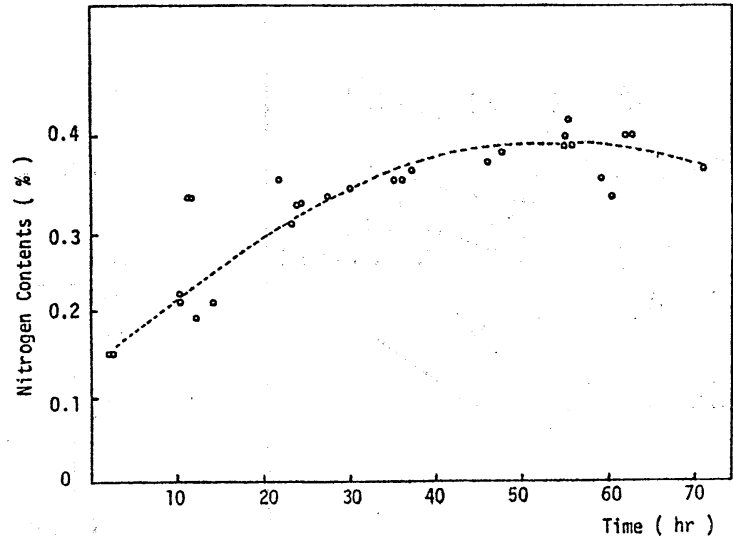

(2) Using Catalyst Mixture Excluding Se

Fig. 6 Relationship between observed values and using time of acid digestion sample-- NO.5 dissected blast furnace coke (Bosh)

傾向がある。また，分解が困難であるからといって， 途中で分解を停止すると，当然のことながら定量值は 低くなる。

\section{6 機器分析法}

今回実施した機器分析法での定量值は, Table 5 お よび Fig.1 に示したように，他の分析法と比較する そかなり所間精度が悪かった。この理由は, 各所でそ れぞれ実施している分析方法で測定することにし，い かなる分析条件の規定もしなかったためと思われる。 実験条件ごとに測定值の傾向を調べた結果, 測定值に 影響を及ぼしていると考えられる条件としては，加熱 温度, 試料粒度, 定量系などが挙げられる。今後, 機
器分析法を規格化していく場合には，協同実験なとに より分析の最適条件を見い出していく必要がある。ま たもう一つの課題としては，セミミクロケルダール 法，セミミクロガス化法との定量值の差がどのような 理由により生ずるのかを調査する必要がある。

\section{4. 結論}

コークス中の窒素定量法について，現状の分析法の 問題点を明確にするための協同実験を行なった結果, 次の結論を得た。

1）セミミクロガス化法は，検討した分析法の中で もっとも所内・所間精度のよい方法であった。

2) 七ミミクロケルダール法の硫酸分解の際に, セ 
用した場合に定量值が低値を示すという点について は，はっきりとした傾向は認められなかった。Fig. 6 に見られるように，セレンを使用しない場合でも，分 解時間が50時間以上と長くなると，定量值が低くなる レン触媒を添加しないと，試料によっては50〜60時間 の加熱が必要である。セレンを加えても，分解に20時 間程度かかるものもある。

3）分解触媒としてセレンを加えた場合と加えない 場合と比較して，分析值に有意差は認められない。た だし，分解時間が必要以上に長すぎないよう，十分な 注意を要する。

4）セミミクロケルダール法とセミミクロガス化法 による定量值を比較すると, 試料によってはガス化法 の方が高くなっている。これは，グラファイト化の進 んだコークスでは, 分解が困難であるため加熱が長時 間に及び，その過程で窒素分の損失が起こったのか， グラファイト化が進むと酸分解では分解しきれない形 態の窒素が生ずるためと考えられる。

5）機器分析法は現状のますでは，かなり分析所間
精度が悪い。今後, 各装置ごとに最適な分析条件を求 めて標準化していく必要があろう。

6) 機器分析法とケルダール法拉よびガス化法の定 量值を比較すると, 差が見られるが，これは単に分析 法だけの問題であるのか，分析される窒素の形態によ るのか，今後明らかにしていく必要があるう。

あとがき

コークス中の窒素分析法に関しては, 従来あまり検 討された例がなく、組織的に行なわれた例としては, 扣气らく本協同実験が世界最初のものといえよう。本 協同実験に参加された分析所各社, ならびに発表を許 可された日本科学技術連盟, サンプリング研究会・分 析小委員会の各社に厚く感謝致します。

\section{文献}

1) A.E. Beet et al., Fuel, 17, 353 (1938)

2) 有機微量定量分析, 有機微量分析想談会編（南江 堂)

3）福山辰夫ほか, 燃協誌， 47,607 (1968)

\title{
Studies on Determination of Nitrogen in Coke Statisitical Analysis of Round-Robin Study
}

\author{
Rieko OHNISHI*, Takashi MrYAZU* and Jiro NITADORI** \\ (*Technical Research Center, Nippon Kokan K.K. \& **National Research \\ Institute for Pollution and Resources, MITI)
}

SYNOPSIS:-Inyerlaboratory experimental work has been undertaken at the $30_{2}^{*}$ different laboratories to study the following items on the determination of nitrogen in coke.

1) Whether there occuers the significant difference between analytical values obtained by Semi-micro Kjeldahl methods using a catalyst mixture including selenum and that excluding it.

2) Whether the difference of analytical values is recognized between in Semimicro Kjeldahl method and Semi-micro Gasification method. The comparative study of instrumental method were also undertaken for a reference.

The following conclusions were derived from the above experiment.

1) Significant bias between results obtained using two kinds of catalyst mixture (including or excluding selenum) in Semi-micro Kjeldahl method can not be observeed if the digestion is carried out carefully.

2) The analysis can be carried out more quickly and more precisely in Semi- 
micro gasification method than in Semi-micro Kjeldahl method.

This is recognized to be because the complete digestion of coke is relatively difficalt in Semi-micro Kjeldahl method.

3) It is considered that the difference of analyical values on coke suffered in high temperature between in Semi-micro Kjeldahl method and in Semimicro gasification, derives from reason below.

a) Final titration is carried out in the condition of still insufficient digestion because the development of graphitization makes the digestion diffcalt in Semi-micro Kjeldahl method.

b) The loss of nitrogen during the digestion usually taking a long time leads to the loweering of observed values.

c) As another possibility, there is not denying the existance of nitrogen which is not completely decomposed by the Semi-micro Kjeldahl method when coke suffered in high temperature is analysed. 